\title{
Transformational Leadership Facilitates Innovation Capability: The Mediating Roles of Interpersonal Trust
}

\author{
Lei Hui ${ }^{1}$, Sengphet Phouvong ${ }^{1,2} \&$ Le Ba Phong ${ }^{1,3}$ \\ ${ }^{1}$ School of Business Administration, Hunan University, Changsha, Hunan, China \\ ${ }^{2}$ Faculty of Education, National University of Laos, Laos \\ ${ }^{3}$ Faculty of Business Management, Hanoi University of Industry, BacTuliem, Hanoi, Vietnam \\ Correspondence: Le Ba Phong, Faculty of Business Management, Hanoi University of Industry, 298 CauDien Road, \\ Bactuliem District, Hanoi city, Vietnam.
}

Received: March 14, 2018

Accepted: April 2, 2018

Online Published: April 9, 2018

doi:10.5430/ijba.v9n3p1

URL: https://doi.org/10.5430/ijba.v9n3p1

\begin{abstract}
Innovation capability is widely accepted as an important means to attain sustain competitive advantage for firms before the rapidly changing of business environment and increasingly competitive pressure. The main goal of this study is to explore an effective way to successfully improving innovation capability for firms based on examining the relationship between transformational leadership style, interpersonal trust, and innovation capability of Vietnamese firms. The authors apply Structural Equations Modeling (SEM) to test the impacts of transformational leadership, interpersonal trust on innovation capability by using data collected from 195 participants in Vietnamese firms. The result revealed that transformational leadership and interpersonal trust significantly affect innovation capability. In addition, interpersonal trust mediates the relationship between transformational leadership and innovation capability. The findings highlights the need of practicing transformational leadership to foster employee trust and finally to enhance innovation capability for firms. The findings of this study contribute to filling the theoretical gaps which call for research on antecedent factors of innovation capability.
\end{abstract}

Keywords: transformational leadership, trust, interpersonal trust, innovation capability, SEM

\section{Introduction}

Since Vietnam's reform and opening-up policy in 1986, Vietnam are becoming one of the influential country in the Association of Southeast Asian Nations and Asia Pacific region. As a developing country in the international markets, Vietnam has been attracting the attention of many foreign firms which have been interested in business and investment in Vietnam. This leads to requirement of changing for Vietnamese firms to effectively adapt to the increasing pressure of competition. Innovation is widely admitted as the key for the survival and growth of organizations (Hurley \& Hult, 1998). As a result, many Vietnamese firms are attempting to become innovator. However, it is not easy to succeed in improving the innovation capability because many firms do not how to develop it properly (Aragón-Correa et al., 2007). In such context, one of the important goals of this study is to find out a specific and effective way to strengthen innovation capability for Vietnamese firms.

Today's business environment has obliged firms to innovate products and services to meet the rapidly changing of customer demands. New ideas, products and services have become the means of competitive advantages and success in business (Jaiswal \& Dhar, 2015). Shalley et al. (2004) contended that the creativity of employee is mainly depended on the individual factors and the context in which they work. Previous studies have indicated many antecedents of employee creativity and innovation such as: Proactive personality, and supervisor support (Kim et al., 2009); Knowledge sharing, and learning (Gong et al., 2009; Le \& Lei, 2018a); innovation climate (Wang et al., 2013); and leadership (Wang et al., 2014). However, leaders can be seen as one the most important factors that have significant influence on innovation because they directly or indirectly participate in all important decisions of an organization (Le \& Lei, 2017).

Leader's behavior is a crucial factor in the work environment that determines individuals' creativity and innovation (Amabile et al., 2004). Prior researchers have found that leaders and their leadership style have a deep contextual impact on an employee's performance to transform into creative and innovative results (Shalley \& Gilson, 2004). 
Among different leadership style, transformational leadership emerges as one of the most effective one. The scholars particularly pay attention to the important role of transformational leadership style because these leaders have significant and positive influences on many key outcomes of firms such as: innovation and marketing differentiation (Menguc et al., 2007); organizational performance (García-Morales et al., 2008); product and process innovation (Birasnav et al., 2013); managerial performance (Nguyen et al., 2016); and organizational justice and trust (Le \& Lei, 2017). As a result, exploring the mechanism that transformational leadership influences innovation capability is very necessary.

Recently, several studies have shown that interpersonal trust positively supports activities of sharing knowledge among individuals (Le \& Lei, 2017; Le \& Lei, 2018b; Le \& Lei, 2018c) which is a decisive factors of organization innovation (Lin, 2007; Liao et al., 2007; Birasnav et al., 2013). However, literature on the direct relationship between interpersonal trust and innovation capability as well as the relationship between transformational leadership style, interpersonal trust, and innovation is still lacking. Consequently, identifying the mechanism of how leadership affects interpersonal trust which in turn improves firms' innovation capability becomes more and more important.

To fill the theoretical gaps, this study develops a research model to investigate the relationship between transformational leadership, interpersonal trust, and innovation capability. Our study attempts to specify the following research questions:

(1) Does transformational leadership have significant effects on interpersonal trust and innovation capability?

(2) Does interpersonal trust mediate between transformational leadership and innovation capability?

(3) Transformational leadership and interpersonal trust, which factor has stronger influences on innovation capability?

To answer these questions, structural equations modeling (SEM) is applied to investigate degree influence of each variable has on the other based on a survey of 195 participants from 50 manufacturing firms in Vietnam. The first goal of this study is provision the empirical evidences on the relationship between TL, interpersonal trust, and innovation capability in a model. Second goal, this study provides specific solutions to improve the innovation capability for Vietnamese firms based on analyzing and discussing more specific the influences of TL on interpersonal trust, which in turn lead to innovation capability. Finally, this study tests the control variables of firm age and firm size to explain for the differences among firms in their innovation capabilities.

\section{Literature Review and Hypotheses Development}

\subsection{Transformational Leadership and Interpersonal Trust}

Transformational leadership was defined as a style of leaders who focus on clearly communicating about organizational goals; acting as the leading force; taking part in proactive coaching; stimulating new skill development between employees and unendingly finding out for new opportunities to generate the development for organization (García Morales et al., 2008; Le \& Lei; 2017). Le and Lei (2018b) indicated that, transformational leadership application is an effective way to build up the employee's trust in leaders which is a key means to attain competitive advantage via stimulating employees to share their knowledge and skills.

Developments in the organizational sciences reflect the importance of interpersonal trust relationships for sustaining individual and organizational effectiveness (McAllister, 1995). Trust is most meaningful in situations in which one party is at risk or vulnerable to another party. For this reason, it becomes critical in relationships between leaders and followers, who by definition have different roles and different levels of status and power (Bligh, 2017). According to Six (2007), interpersonal trust is a psychological state, willing to accept vulnerability to the actions of another party, based on the expectation that the other will perform a particular action that is important to them. Trust might be seen as a mutual understanding and respectfulness among two parties, helped them to overcome vulnerabilities.

The relationship between transformational leadership and trust interpersonal trust has received little attention from empirical researchers; however, these relationships also are expressed quite clearly in several previous studies. Farris et al. (1973) indicated that leaders who maintain open communication strengthen perceptions of trust among individual in an organization. Characteristics of transformational leaders (including being charismatic, inspirational, and emphasizing the important role of emotions and values) will stimulate communication processes (Bass \& Avolio, 2000; García Morales et al., 2008), thereby creating open communication and individuals' trust in each other. Lewicki et al. (1998) stated that a decisive characteristic of high trust relationships is the degree to which both parties recognize each other's values; whilst theories of transformational leadership consider employees the most valuable resource in the firm and emphasize the important role of emotions and values (Bass \& Avolio, 2000; García Morales 
et al., 2008); hence, individuals will have more opportunities to know each other's values and to build trust among them. Gillespie and Mann (2004) stated that there is a direct relationship between transformational leadership and interpersonal trust. Recently, Le and Lei (2018a) showed the evidence that, transformational leadership is positively related to interpersonal trust at both aspect: reliance-based trust (ready to rely on another's work-related skills, abilities and knowledge), and disclosure-based trust (ready to disclose work-related sensitive aspects or personal opinions and information to others).

Based on above discussions, we propose following hypothesis (Figure 1):

H1: Transformational leadership significantly correlates interpersonal trust.

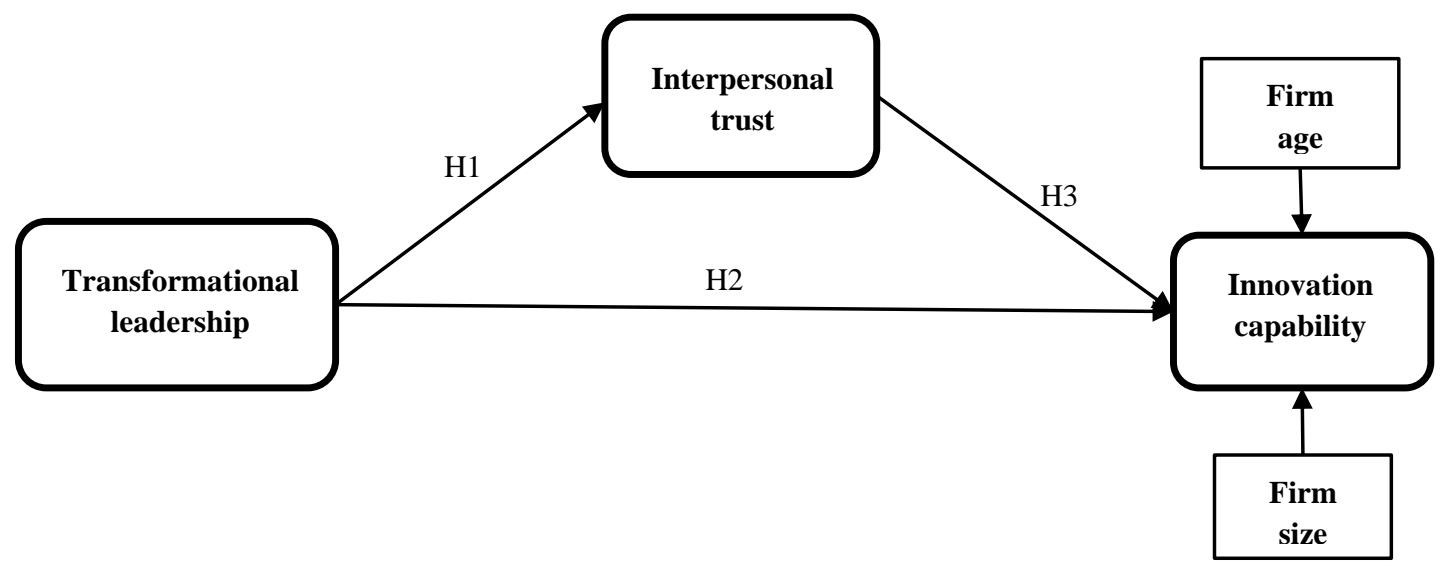

Figure 1. Conceptual model

\subsection{Transformational Leadership and Innovation Capability}

Innovation capability is defined as the capability of applying or creating of new products, services, work processes and management procedures to attain competitive advantage for firms (Drucker, 2014). Among different factors that influence innovation capability of firms leaders have a decisive role in generating innovation (Tushman \& Nadler, 1986) due to they have a key role in all decisions of an organization and can create a appropriate culture for enhancing the abilities and practices to promote innovation capability (Van de Ven, 1986).

Many prior researches pointed out that, transformational leadership has important effects on firm innovation (Tushman \& Nadler, 1986; Birasnav et al., 2013). Transformational leadership facilitates innovation by paying great attention on building innovative teams and transmitting stronger motivation to innovate (Tushman \& Nadler, 1986; Senge et al., 1994). Recently, Birasnav et al.'s (2013) empirical research based on the data from 119 service firms located in Kingdom of Bahrain indicated that transformational leadership directly influences or indirectly impact on organizational capability for product and process innovation though its effects on knowledge acquisition, knowledge transfer, and knowledge application.

Based on above discussion support transformational leadership's effect on innovation capability, thus following hypotheses is posed:

H2: Transformational leadership positively impacts on innovation capability.

\subsection{Interpersonal Trust and Innovation Capability}

Trust is a social capital resource that is "embedded" in relationships between people. It is socially constructed based on specific relationship, purposes and meanings (Dovey, 2009). It is the foundation for building and developing innovation capability for firms. Indeed, although, the relationship between interpersonal trust and innovation capability has not been attracted the great attention from prior researches (Ellonen et al., 2008), the correlation among these factors is also explained by some authors, for example: according to Clegg et al. (2002), trust is involved with the innovation process. It reflects the expectancy that the organisation takes one's ideas seriously to positively implement those ideas. Judge (2011) and Soparnot (2011) indicated that change capacity or innovation capability needs employees to trust in their organization and leadership. Dovey (2009) supposed that, the degree of innovation depends on level of interpersonal trust. The author also showed that, trust in a supervisor is positively 
correlated with a subordinate's innovative behavior. High levels of trust have a positive effect on the effectiveness and quality of organisational knowledge sharing and innovation (Dovey, 2009). In line with this point of view, Le and Lei (2018b) pointed out that trust among employees is positively and significantly associated with knowledge sharing and information exchange which is the fundamental for firms to carry out necessary changes and innovation as because knowledge and learning capability is positively related to firm's innovation capability at two faces: innovation speed and innovation quality (Le \& Lei, 2018a).

Although, interpersonal trust is an important variable in the field of organizational behavior, the literature and empirical evidence on relationship between interpersonal trust and innovation capability is still limited. As a result, based on above discussion we proposed following hypothesis:

H3: Interpersonal trust positively influences firm's innovation capability.

\section{Research Methodology}

\subsection{Sample and Data Collection}

Empirical data were collected through a survey of 50 manufacturing firms in Hanoi and Haiphong-two developed cities in Vietnam. We communicated with representatives of these firms by phone and/or make personal visits to interpret the goals of the study and inquire for the assistance in collecting data. The participants are employees at some important departments of firms, such as: administration, operation, R\&D, marketing and sales. This study issues 350 questionnaires and receives 231 one in final, among which 195 ones are valid (55.7\% valid rate). Total of 195 respondents, $111(56.9 \%)$ were male and $84(43.1 \%)$ were female. They answered the issues relating to the study variables, including: transformational leadership; interpersonal trust, and innovation capability in their firm.

\subsection{Variable Measurement}

To ensure the validity and reliability of the study, items that used to measure variables, have been previously developed and used from previous studies. All constructs were measured using multiple items and all items are measured via five-point Likert-type scales, ranging from "1" (strongly disagree) to "5" (strongly agree).

Transformational leadership: We recognized participants' perceptions of their supervisors' transformational leadership with four items that was designed by Podsakoff et al. (1996) and was used by Le and Lei (2017) for diverse aspects of transformational leadership. A sample is: "Our leaders are capable of motivating and guiding their followers/employees on the job".

Interpersonal trust: To measure interpersonal trust, we used five items designed by Yilmaz and Hunt's (2001) interpersonal trust at work scale. A sample is: "I consider my colleagues as people who can be counted on to do what is right"

Innovation capability: innovation capability reflects firm's ability in offering customers new goods and services, as well as firm's ability in applying/using the new methods or process to get better performance. We used six scales from Lin (2007) to measure innovation capability of firms. A samples item is: "Our firm is frequently the first to market new products and services".

Control variables: This study investigate the control role of firm age and firm size to access for the differences in innovation capabilities among firms.

\subsection{Data Analysis Methods}

This study uses the software of SPSS and AMOS version 21 to process data. Confirmatory factor analysis (CFA) and Structural equations modeling (SEM) is applied to examine the validity and reliability of the constructs as well as to assess the effects of the variables in the research model.

\section{Data Analysis and Results}

\subsection{Measurement Model}

A series of tests are implemented to evaluate the constructs' reliability and validity for examples: Cronbach's alpha coefficients to test reliability of the measures (Nunnally \& Bernstein, 1994); confirmatory factor analysis (CFA) to test for the convergent validity; comparing the squared correlations between the latent variables and square root of average variance extracted (AVE) to test the discriminant validity of measures (Fornell \& Larcker, 1981). Results in Table 1 and Table 2 showed fit indices of the model, suggesting that the relationships among latent constructs fit the data. 
Table 1 shows AVE, CR, mean, standard deviation (SD) and C $\alpha$ of every construct. It shows that the square root of AVE for each construct is higher than the correlations among constructs in the model provided strong support for the construct reliability, as well as for the convergent and discriminant validity of the scales.

Table 1. Descriptive statistics and average variances extracted from constructs

\begin{tabular}{lllllllllll}
\hline Construct & AVE & CR & C $\alpha$ & Mean & SD & TL & IT & IC & FS & FA \\
\hline Transformational leadership (TL) & 0.82 & 0.95 & 0.95 & 3,39 & 0.64 & $\mathbf{0 . 8 3}$ & & & & \\
Interpersonal trust (IT) & 0.74 & 0.93 & 0.93 & 3.69 & 0.59 & 0.67 & $\mathbf{0 . 8 4}$ & & & \\
Innovation capability (IC) & 0.85 & 0.97 & 0.97 & 3.77 & 0.68 & 0.70 & 0.72 & $\mathbf{0 . 8 5}$ & & \\
Firm size (FS) & 1 & 1 & NA & 1.90 & 0.80 & 0.38 & 0.44 & 0.47 & $\mathbf{0 . 8 5}$ & \\
Firm age (FA) & 1 & 1 & NA & 2.05 & 0.58 & 0.41 & 0.58 & 0.47 & 0.35 & $\mathbf{0 . 9 0}$ \\
\hline
\end{tabular}

Note: $C \alpha \geq 0.7 ; C R \geq 0.7 ; A V E \geq 0.5 ; S D$ : standard deviation. Diagonal elements (in bold) are the square root of the $A V E ;$ Off-diagonal elements are the correlations among constructs

Table 2 and Table 3 show that all fit indices of the measurement model and structural model are at a satisfactory level, the model fit the data.

Table 2. Overall fit index of the CFA model

\begin{tabular}{lcc}
\hline Fit index & Scores & Recommended threshold value \\
\hline Absolute fit measures & & \\
CMIN/df & 1.445 & $\leq 2^{\mathrm{a}} ; \leq 5^{\mathrm{b}}$ \\
GFI & 0.914 & $\geq 0.90^{\mathrm{a}} ; \geq 0.80^{\mathrm{b}}$ \\
RMSEA & 0.048 & $\leq 0.08^{\mathrm{a}} ; \leq 0.10^{\mathrm{b}}$ \\
Incremental fit measures & & \\
NFI & 0.961 & $\geq 0.90^{\mathrm{a}} ;$ \\
AGFI & 0.877 & $\geq 0.90^{\mathrm{a}} ; \geq 0.80^{\mathrm{b}}$ \\
CFI & 0.987 & $\geq 0.90^{\mathrm{a}} ;$ \\
\hline
\end{tabular}

Note: A Acceptability: acceptable; b Acceptability: marginal

Table 3. Overall fit index of the structural model

\begin{tabular}{lcc}
\hline Fit index & Scores & Recommended threshold value \\
\hline Absolute fit measures & & \\
CMIN/df & 2.477 & $\leq 2^{\mathrm{a}} ; \leq 5^{\mathrm{b}}$ \\
GFI & 0.855 & $\geq 0.90^{\mathrm{a}} ; \geq 0.80^{\mathrm{b}}$ \\
RMSEA & 0.087 & $\leq 0.08^{\mathrm{a}} ; \leq 0.10^{\mathrm{b}}$ \\
Incremental fit measures & & \\
NFI & 0.929 & $\geq 0.90^{\mathrm{a}} ;$ \\
AGFI & 0.803 & $\geq 0.90^{\mathrm{a}} ; \geq 0.80^{\mathrm{b}}$ \\
CFI & 0.956 & $\geq 0.90^{\mathrm{a}} ;$ \\
\hline
\end{tabular}

Note: A Acceptability: acceptable; b Acceptability: marginal

\subsection{Structural Model}

This section presents the main result of the hypothesis testing of the structural relationship among the variables in research model (Figure 2, Table 4 and Table 5) 


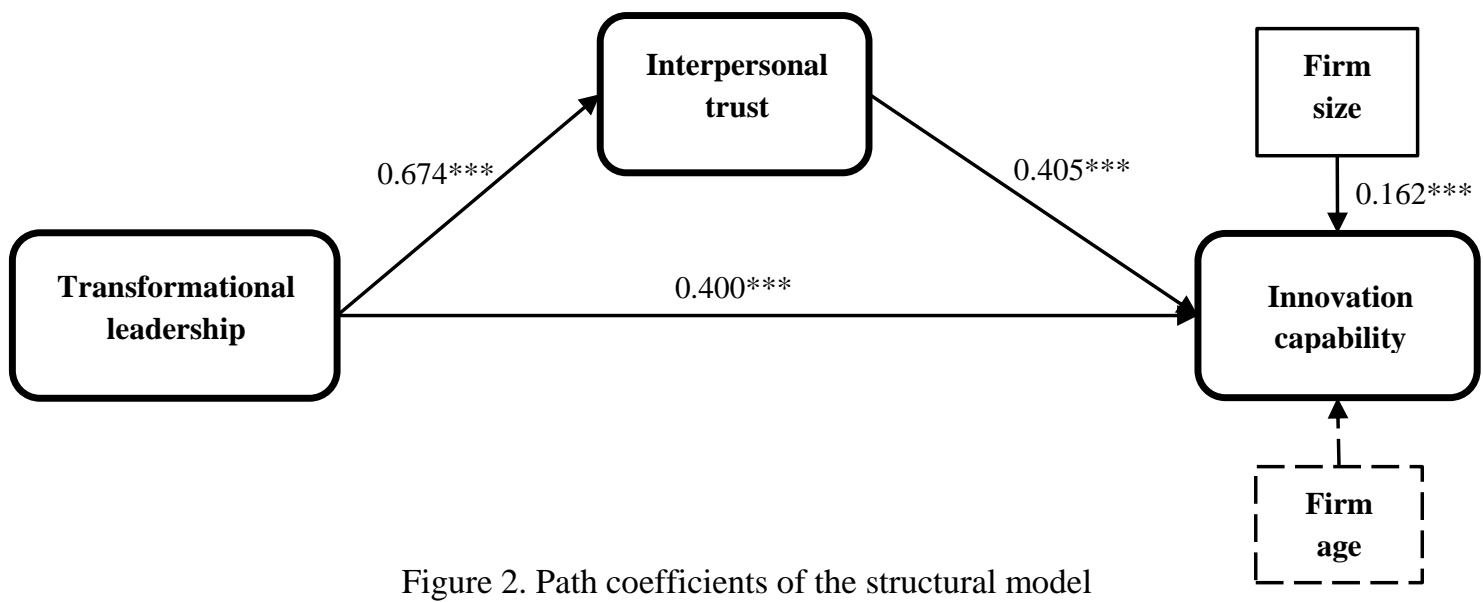

Note: $* * * p<0.001$ level; ---: non-significant

Table 4. Structural model results

\begin{tabular}{|c|c|c|c|c|}
\hline Hypotheses & Proposal effect & Estimate & $\mathrm{P}$ & Results \\
\hline $\mathrm{H} 1: \mathrm{TL} \rightarrow \mathrm{IT}$ & + & $0.674 * * *$ & $<0.001$ & Supported \\
\hline $\mathrm{H} 2: \mathrm{TL} \rightarrow \mathrm{IC}$ & + & $0.400 * * *$ & $<0.001$ & Supported \\
\hline H3: IT $\rightarrow$ IC & + & $0.405^{* * *}$ & $<0.001$ & Supported \\
\hline Control variables & Effect & Estimate & $\mathrm{P}$ & Results \\
\hline Firm age $\rightarrow$ IC & + & 0.070 & 155 & Not Supported \\
\hline Firm size $\rightarrow$ IC & + & $0.162 * * *$ & 0.001 & Supported \\
\hline
\end{tabular}

Note: $* * * p<0.001$ level.

\subsubsection{Direct Effect Analysis}

The results (Figure 2 and Table 4) show that all the hypotheses are supported because the direct effects of TL on interpersonal trust and direct effects of TL, interpersonal trust on innovation capability are quite large and statistically significant. Specifically:

The results showed that TL positively influence interpersonal trust with $\beta=0.674(p<0.001)$ which provides evidence to support $\mathrm{H} 1$.

The results also confirm $\mathrm{H} 2$ relating to the positive impacts of TL on innovation capability $(\beta=0.400 ; p<0.001)$

Hypotheses of $\mathrm{H} 3$ refers to positive influence of interpersonal trust on innovation capability is also supported $(\beta=$ $0.405 ; p<0.001)$. The finding showed that the impacts of TL and interpersonal trust on innovation capability are not significantly different.

Finally, the findings in Table 4 showed that, the control role of firm age was not supported $(\beta=0.070 ; p=155)$. In contrast, Table 4 supported for the control role of firm size on innovation capabilities $(\beta=0.162 ; p=0.001)$.

\subsubsection{Indirect and Total Effect Analysis}

This study does not just show the evidence on the direct effect of TL on innovation capability, it also explores the mediating roles of interpersonal trust in the relationship between TL and innovation capability based on using the bootstrapping technique with 2,000 iterations as suggested by Preacher and Hayes (2008) (see Table 5).

Table 5. Confidence intervals of indirect effects

\begin{tabular}{rccccc}
\hline Path & $\begin{array}{r}\text { Direct } \\
\text { effects }\end{array}$ & $\begin{array}{c}\text { Indirect } \\
\text { effects }\end{array}$ & \multirow{2}{*}{$\begin{array}{c}\text { Total } \\
\text { effects }\end{array}$} & $\begin{array}{c}\text { Bias-corrected confidence intervals } \\
\text { confidence level }\end{array}$ & $\begin{array}{c}\text { Upper } \\
\text { confidence level }\end{array}$ \\
\hline Note: $* * * p<0.001$ & $0.400 * * *$ & $0.273 * * *$ & $0.673 * * *$ & 0.182 & 0.373 \\
\hline TL $\rightarrow$ IT & & & & &
\end{tabular}


Table 5 indicated that TL's indirect effects on innovation capability $(\beta=0.273 ; p<0.001)$ through the mediating role of interpersonal trust is statistically significant in the confidence intervals $(0.182-0.373)$. So, the finding in Table 5 firstly confirms the mediating role of interpersonal trust in the relationship between TL and innovation capability.

\section{Discussions and Implications}

Improving innovation capability is always the urgent and necessary requirements to create competitive advantage and provide more valuable goods and services to customers. In the situation that many Vietnamese firms invested a lot of effort and much of money into improving innovation capability they still getting difficult and trying to explore the right ways to successful innovation. Our research model based on investigating the relationship between TL, interpersonal trust and innovation capability has made significantly contribution to both practical and theoretical initiatives on innovation capability by some following main reasons.

First, the main objective of this study is to examine the influence of TL and interpersonal trust on firms' innovation capability based on using a data base of 50 Vietnamese manufacturing firms. This study contributes to finding the new and right way for Vietnamese firms to improve their innovation capability. The findings revealed that, TL have a crucial role in building interpersonal trust and enhancing innovation capability. Consequently, firm leader need to strengthen the practice of TL style for the purposes of innovation by: continually looking for new opportunities for the units, departments and organization; building up clear common view as well as specific goals of individuals, units and organization; establishing the emotional links with employees/followers and inspiring them to higher values; focusing on creating motivation to work for employees; and always acting as the organization's leading force.

Second, a significant contribution of this study is that it has filled the research gaps due to lack of research and empirical evidence on TL's influence on innovation capability (García Morales et al., 2008). The empirical findings of this study verified the relationships between the factors in the proposal model with all the hypotheses are confirmed. The study has pointed out a possible mechanism through which TL practices and interpersonal trust promote innovation capability for firms. The mediating roles interpersonal trust in the relationship between TL and innovation capabilities is supported. The implication is that TL practices can be one of the most effective ways facilitating innovation. By practicing TL style, leadership can influence innovation capability directly or indirectly through building the trust among employees in an organization.

Third, by testing the control role of firm age and firm size, this study shows that, firm age has no significant impact on innovation capability. In contrast, firm size has considerable influences on innovation capabilities. The findings implied that, the greater firms will have greater opportunity to innovate. The main reason may be that, the greater firms have enough capital, necessary resource and technology to change new methods and ideas into reality. Therefore, paying more attention to accumulation of resources and experience is one of the key measures to improve the capacity of innovation for small firms.

This study has several limitations that also suggest directions for future research. First, unwanted ability may appears in this study is that the causal relationships may change in the long term due to the cross-sectional design that we used to investigate the relationship between the latent variable in the proposal research. A longitudinal study will help to overcome this limitation and consolidate the result. Second, this study has not explored the moderating roles of firm age and firm size in the relationship between the considering variables, future research may test the relationship between these latent variables based on the moderating variables of firm age and firm size have clearer and fuller understanding of these variables towards innovation capability of different firms. Finally, innovation is one of the key means of attaining competitive advantage and enhancing organizational performance before the context of increasing competitive pressure (Le \& Lei, 2018a). Accordingly, future research need to continuously identify or investigate the influences of antecedents or strategic factors (such as leadership characteristics, knowledge management capability, and individuals' positive psychological capital) on some specific aspects of innovation such as product and process innovation; radical and incremental innovation to increasing more understanding of the new and effective pathways lead to innovation capabilities of firms.

\section{References}

Amabile, T.M., Schatzel, E.A., Moneta, G.B., \& Kramer, S.J. (2004). Leader behaviors and the work environment for creativity: Perceived leader support. The Leadership Quarterly, 15(1), 5-32. https://doi.org/10.1016/j.leaqua.2003.12.003 
Aragón-Correa, J.A., García-Morales, V.J., \& Cordón-Pozo, E. (2007). Leadership and organizational learning's role on innovation and performance: Lessons from Spain. Industrial Marketing Management, 36(3), 349-359. https://doi.org/10.1016/j.indmarman.2005.09.006

Bass, B M., \& Avolio, B.J. (2000). MLQ: Multifactor leadership questionnaire. Mind Garden.

Birasnav, M., Albufalasa, M., \& Bader, Y. (2013). The role of transformational leadership and knowledge management processes on predicting product and process innovation: An empirical study developed in Kingdom of Bahrain. Tékhne, 11(2), 64-75. https://doi.org/10.1016/j.tekhne.2013.08.001

Bligh, M.C. (2017). Leadership and Trust. Leadership Today, 21-42.

Clegg, C., Unsworth, K., Epitropaki, O., \& Parker, G. (2002). Implicating trust in the innovation process. Journal of Occupational and Organizational Psychology, 75(4), 409-422. https://doi.org/10.1348/096317902321119574

Dovey, K. (2009). The role of trust in innovation. The Learning Organization, 16(4), 311-325. https://doi.org/10.1108/09696470910960400

Drucker, P. (2014). Innovation and entrepreneurship. Routledge.

Ellonen, R., Blomqvist, K., \& Puumalainen, K. (2008). The role of trust in organisational innovativeness. European Journal of Innovation Management, 11(2), 160-181. https://doi.org/10.1108/14601060810869848

Farris, G.F., Senner, E.E., \& Butterfield, D.A. (1973). Trust, culture, and organizational behavior. Industrial Relations: A Journal of Economy and Society, 12(2), 144-157. https://doi.org/10.1111/j.1468-232X.1973.tb00544.x

Fornell, C., \& Larcker, D.F. (1981). Evaluating structural equation models with unobservable variables and measurement error. Journal of Marketing Research, 18(1), 39-50. https://doi.org/10.2307/3151312

Garcia-Morales, V.J., Matias-Reche, F., \& Hurtado-Torres, N. (2008). Influence of transformational leadership on organizational innovation and performance depending on the level of organizational learning in the pharmaceutical sector. Journal of Organizational Change Management, 21(2), 188-212. https://doi.org/10.1108/09534810810856435

Gong, Y., Huang, J.C., \& Farh, J.L. (2009). Employee learning orientation, transformational leadership, and employee creativity: The mediating role of employee creative self-efficacy. Academy of Management Journal, 52(4), 765-778. https://doi.org/10.5465/AMJ.2009.43670890

Gillespie, N.A., \& Mann, L. (2004). Transformational leadership and shared values: The building blocks of trust. Journal of Managerial Psychology, 19(6), 588-607. https://doi.org/10.1108/02683940410551507

Hurley, R.F., \& Hult, G.T.M. (1998). Innovation, market orientation, and organizational learning: an integration and empirical examination. The Journal of Marketing, 42-54. https://doi.org/10.2307/1251742

Jaiswal, N.K., \& Dhar, R.L. (2015). Transformational leadership, innovation climate, creative self-efficacy and employee creativity: A multilevel study. International Journal of Hospitality Management, 51, 30-41. https://doi.org/10.1016/j.ijhm.2015.07.002

Judge, W.Q. (2011). Building Organizational Capacity for Change: The Leader's New Mandate. Business Expert Press. https://doi.org/10.4128/9781606491256

Kim, T.Y., Hon, A.H., \& Crant, J.M. (2009). Proactive personality, employee creativity, and newcomer outcomes: A longitudinal study. Journal of Business and Psychology, 24(1), 93-103. https://doi.org/10.1007/s10869-009-9094-4

Le, P.B., \& Lei, H. (2017). How transformational leadership supports knowledge sharing: Evidence from Chinese manufacturing and service firms. Chinese Management Studies, 11(3), 479-497. https://doi.org/10.1108/CMS-02-2017-0039

Le, P.B., \& Lei, H. (2018a). The effects of innovation speed and quality on differentiation and low-cost competitive advantage: The case of Chinese firms. Chinese Management Studies. https://doi.org/10.1108/CMS-10-2016-0195

Le, P.B., \& Lei, H. (2018b). Fostering knowledge sharing behaviours through ethical leadership practice: the mediating roles of disclosure-based trust and reliance-based trust in leadership. Knowledge Management Research \& Practice, 1-13. https://doi.org/10.1080/14778238.2018.1445426 
Le, P.B., \& Lei, H. (2018c). The mediating role of trust in stimulating the relationship between transformational leadership and knowledge sharing processes. Journal of Knowledge Management. https://doi.org/10.1108/JKM-10-2016-0463

Lewicki, R.J., McAllister, D.J., \& Bies, R.J. (1998). Trust and distrust: New relationships and realities. Academy of Management Review, 23(3), 438-458.

Liao, S.H., Fei, W.C., \& Chen, C.C. (2007). Knowledge sharing, absorptive capacity, and innovation capability: an empirical study of Taiwan's knowledge-intensive industries. Journal of Information Science, 33(3), 340-359. https://doi.org/10.1177/0165551506070739

Lin, H.F. (2007). Knowledge sharing and firm innovation capability: an empirical study. International Journal of Manpower, 28(3/4), 315-332. https://doi.org/10.1108/01437720710755272

McAllister, D.J. (1995). Affect-and cognition-based trust as foundations for interpersonal cooperation in organizations. Academy of Management Journal, 38(1), 24-59. https://doi.org/10.2307/256727

Menguc, B., Auh, S., \& Shih, E. (2007). Transformational leadership and market orientation: Implications for the implementation of competitive strategies and business unit performance. Journal of Business Research, 60(4), 314-321. https://doi.org/10.1016/j.jbusres.2006.12.008

Nunnally, J.C., \& Bernstein, I. (1994). Elements of statistical description and estimation, in Psychometric Theory (3rd ed.). McGraw-Hill Series in Psychology.

Nguyen, T.T., Mia, L., Winata, L., \& Chong, V.K. (2017). Effect of transformational-leadership style and management control system on managerial performance. Journal of Business Research, 70, 202-213. https://doi.org/10.1016/j.jbusres.2016.08.018

Podsakoff, P.M., MacKenzie, S.B., \& Bommer, W.H. (1996). Transformational leader behaviors and substitutes for leadership as determinants of employee satisfaction, commitment, trust, and organizational citizenship behaviors. Journal of Management, 22(2), 259-298. https://doi.org/10.1177/014920639602200204

Preacher, K.J., \& Hayes, A.F. (2008). Asymptotic and resampling strategies for assessing and comparing indirect effects in multiple mediator models. Behavior Research Methods, 40(3), 879-891. https://doi.org/10.3758/BRM.40.3.879

Senge, P., Roberts, C., Ross, R., Smith, B., \& Kleiner, A. (1994). The Fifth Discipline FieldbookDoubleday. New York.

Shalley, C.E., \& Gilson, L.L. (2004). What leaders need to know: A review of social and contextual factors that can foster or hinder creativity. The Leadership Quarterly, 15(1), 33-53. https://doi.org/10.1016/j.leaqua.2003.12.004

Shalley, C.E., Zhou, J., \& Oldham, G.R. (2004). The effects of personal and contextual characteristics on creativity: Where should we go from here? Journal of Management, 30(6), 933-958. https://doi.org/10.1016/j.jm.2004.06.007

Six, F.E. (2007). Building interpersonal trust within organizations: a relational signalling perspective. Journal of Management \& Governance, 11(3), 285-309. https://doi.org/10.1007/s10997-007-9030-9

Soparnot, R. (2011). The concept of organizational change capacity. Journal of Organizational Change Management, 24(5), 640-661. https://doi.org/10.1108/09534811111158903

Tushman, M., \& Nadler, D. (1986). Organizing for innovation. California Management Review, 28(3), 74-92. https://doi.org/10.2307/41165203

Van de Ven, A.H. (1986). Central problems in the management of innovation. Management Science, 32(5), 590-607. https://doi.org/10.1287/mnsc.32.5.590

Wang, C.J., Tsai, H.T., \& Tsai, M.T. (2014). Linking transformational leadership and employee creativity in the hospitality industry: The influences of creative role identity, creative self-efficacy, and job complexity. Tourism Management, 40, 79-89. https://doi.org/10.1016/j.tourman.2013.05.008

Wang, P., Rode, J.C., Shi, K., Luo, Z., \& Chen, W. (2013). A workgroup climate perspective on the relationships among transformational leadership, workgroup diversity, and employee creativity. Group \& Organization Management, 38(3), 334-360. https://doi.org/10.1177/1059601113488163

Yilmaz, C., \& Hunt, S.D. (2001). Salesperson cooperation: The influence of relational, task, organizational, and personal factors. Journal of the Academy of Marketing Science, 29(4), 335-357. https://doi.org/10.1177/03079450094207 